\title{
特別講演
}

Kupffer 細胞の発生, 分化と肉芽腫形成

内 藤 眞

新潟大学医学部病理学第 2 講座

Kupf fer細胞は肝類洞にあって流血中の物質を活発に 取り込むとともに生物活性物質の産生、分泌を介して 代謝、免疫機構に多面的に関与する生体内最大の組織 マクロファージである。本細胞の起源については幾多 の論争が続けられてきたが、van Furth (1972)の提唱 した単核食細胞系 (MPS)によると本細胞は骨䯣造血に由 来し、単芽球、前単球、単球への分化段階を経て分化 した分裂能を有さない終末細胞とみなされている。し かし、演者らはこれまでKupf fer細胞は個体発生上肝原 基に発生する原始・胎生マクロファージに由来し、生 後も種々の条件下で活発に増殖し、維持される細胞群 であることを明らかにしてきた。本講演ではKupffer細 胞の個体発生、分化機構と肉芽腫形成における役割に ついて述べる。

\section{Kupf fer細胞の個体発生}

哺乳類においてマクロファージは卵黄囊造血巣に初 発する。マウス卵黄哄では造血の開始と同時に小型で 未熟な形態の原始マクロファージが発生し、より成熟 した胎生マクロファージに分化する。原始・胎生マク ロファージは血流を介して肝原基に移動定着し、増殖 する。肝の胎生マクロファージはやがて在住マクロフ アージとしての抗原やペルオキシダーゼ活性を発現し、 出生前にKupf f er細胞としての性格を獲得する。一方、 単球系細胞は胎生早期には未発達で、肝造血後半に確 立する。胎生造血巣ではマクロファージ前駆細胞も検 出され、初期肝造血巣ではGM-CFCが、肝造血後半には さらにM-CFCが発生増殖する。胎生造血細胞の軟寒天培 地での培養では単球系細胞のコロニー形成がみられる のに対し、マウス骨髄間質細胞株ST2を用いた初期肝造 血細胞の培養実験では原始・胎生マクロファージコロ ニーと単球系細胞コロニーが別個に形成される。以上 の成績から、原始・胎生マクロファージはGM-CFCまた はその前駆細胞に由来すると考慮され、Kupf fer細胞も その細胞系に属し、単球系マクロファージと異なる分 化過程を辿る細胞系とみなされる。

\section{2. 単球減少マウスにおけるKupf fer細胞の動態} MPSによるとKupf fer細胞には増殖能が欠如し、その
寿命はマウスで 4 日間と計算されている。しかし、 stront ium-89の選択的骨鰱照射による単球減少症マウ スでは、Kupf fer細胞は 6 週間にわたり維持され、増殖 能の六進が観察される。このことからKupf fer細胞は単 球の補給のない状態でも自己増殖によって長期間生存 可能な細胞系と考えられる。

3. M-CSF欠損マウスにおけるKupf fer細胞の動態 マクロファージコロニー刺激因子 (M-CSF) 活性久損マ ウス $(o p / o p)$ では単球はほとんどなく、Kupf fer細胞は 正常マウスの30\%にすぎない。op/opマウスのKupf fer 細胞はM-CSF非依存性マクロファージとみなされ、形態 的には未熟である。op/opマウスにM-CSFを投与すると Kupf fer細胞は急速に増殖、回復し、形態的にも成熟す る。op/opマウスと近似したKupf fer細胞の変化は低蛋 白食飼育マウスでも観察され、肝でのM-CSFmRNAの発現 減少が証明される。これらの成績はKupf fer細胞の分化、 増殖にM-CSFが重要な役割を演ずることを示している。

4. Kupf fer細胞枯渴後の再生

リポソームに封入したクロドロネートはマクロファ ージに取り込まれ、強力な細胞傷害性を発揮する。マ ウスに本剂を静注すると 3 日間Kupf fer細胞は完全に消 滅し、その後小型のKupf fer細胞が発現、增殖して 2 週 後には回復する。一方Kupf fer細胞枯渴時に肝内に MCFCが増殖することから、肝にKupf fer細胞前駆細胞が 常在し、Kupf fer細胞の消失時にその代償機構として機 能する可能性が示唆される。

5. 肉芽腫形成におけるKupf fer 細胞の役割 炎症においては単球系細胞が重要であるが、Kupf fer 細胞の役割は明らかではない。グルカンやザイモサン を静注するとマウス肝には単球の增加、Kupf fer細胞の 増殖、類上皮細胞や多核巨細胞を主とする肉芽腫の形 成が見られる。strontium-89投与単球減少マウスでも Kupf fer細胞は増殖、集合し、類上皮細胞、多核巨細胞 へと変態してKupf fer細胞のみからなる肉芽腫を形成す る。op/opマウスでも単球の減少とマクロファージへの 分化障害にもかかわらずKupf fer細胞の増生と集合によ り少数の類上皮細胞性肉芽腫が形成され、この過程に 
はM-CSF以外のマクロファージ増殖因子、ことにGM-CSF の関与が示唆される。このマウスにM-CSFを投与すると 単球の増加、Kupf fer細胞の增殖が誘起され、肉芽腫形 成も充進し、肉芽腫形成における単球とM-CSFの重要性 も再確認される。一方リポソーム封入クロドロネート によるKupffer細胞除去マウスでは、単球の增加にもか かわらず肉芽腫形成やIL-1などのサイトカイン発現が
顕著に抑制され、肉芽腫形成におけるKupf fer細胞の重 要性が明らかにされた。

Kupf fer細胞は肝という微小環境のなかで発生し、在 住マクロファージとして分化し、多彩な役割を果たす。 その発生分化機構にはM-CSFPGM-CSFなどの増殖因子が 深く関与する。以上、われわれの行った研究成績を中 心に解説する。 